\title{
Evidence for the Involvement of Descending Pain-Inhibitory Mechanisms in the Antinociceptive Effect of Hecogenin Acetate
}

Kelly Barbosa Gama, ${ }^{\dagger}$ Jullyana S. S. Quintans, ${ }^{\ddagger}$ Ângelo R. Antoniolli, ${ }^{\ddagger}$ Lucindo J. Quintans-Júnior, Wagno Alcântara Santana, ${ }^{\S}$ Alexsandro Branco, ${ }^{\S}$ Milena Botelho Pereira Soares, ${ }^{\perp, \|}$ and Cristiane Flora Villarreal ${ }^{*}, \dagger, \perp$

\author{
${ }^{\dagger}$ Faculdade de Farmácia, Universidade Federal da Bahia, Salvador, BA, CEP 40170-290, Brazil \\ ${ }^{\ddagger}$ Departamento de Fisiologia, Universidade Federal de Sergipe, Aracaju, Sergipe, CEP 49100-000, Brazil \\ ${ }^{\S}$ Universidade Estadual de Feira de Santana, Feira de Santana, BA, CEP 44036-900, Brazil \\ ${ }^{\perp}$ Centro de Pesquisas Gonçalo Moniz, Fundação Oswaldo Cruz, Salvador, BA, CEP 40296-710, Brazil \\ ${ }$ Centro de Biotecnologia e Terapia Celular, Hospital São Rafael, Salvador, BA, CEP 41253-190, Brazil
}
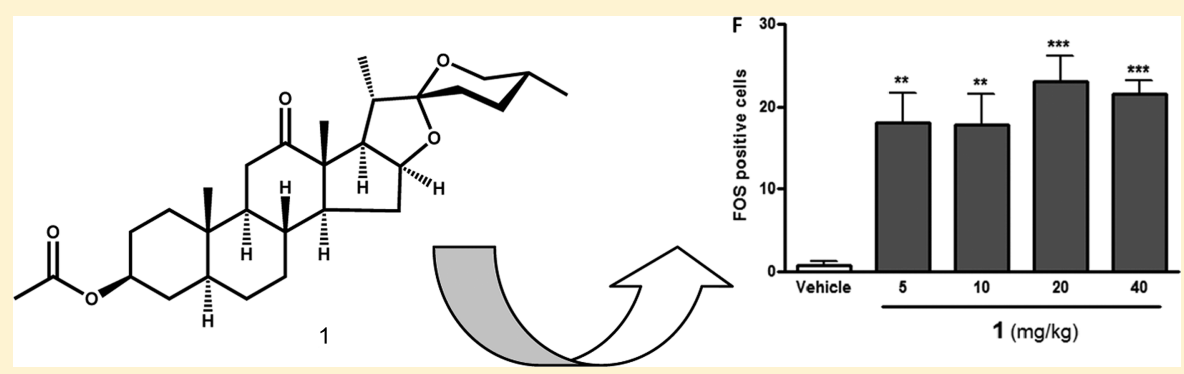

ABSTRACT: Hecogenin is a sapogenin present in the leaves of species from the Agave genus, with a wide spectrum of reported pharmacological activities. The present study was undertaken to evaluate whether hecogenin acetate (1) has antinociceptive properties and to determine its mechanism of action. The nociceptive threshold was evaluated using the tail flick test in mice. Mice motor performance was evaluated in a Rotarod test. By using Fos expression as a marker of neural activation, the involvement of the periaqueductal gray in 1-induced antinociception was evaluated. Intraperitoneal administration of 1 (5-40 $\mathrm{mg} / \mathrm{kg}$ ) produced a dose-dependent increase in the tail flick latency time compared to vehicle-treated group $(p<0.01)$. Mice treated with $1(40 \mathrm{mg} / \mathrm{kg})$ did not show motor performance alterations. The antinociception of $1(40 \mathrm{mg} / \mathrm{kg})$ was prevented by naloxone (nonselective opioid receptor antagonist; $5 \mathrm{mg} / \mathrm{kg}$ ), CTOP ( $\mu$-opioid receptor antagonist; $1 \mathrm{mg} / \mathrm{kg}), \mathrm{nor}-\mathrm{BNI}(\kappa$ opioid receptor antagonist; $0.5 \mathrm{mg} / \mathrm{kg}$ ), naltrindole $\left(\delta\right.$-opioid receptor antagonist; $3 \mathrm{mg} / \mathrm{kg}$ ), or glibenclamide (ATP-sensitive $\mathrm{K}^{+}$ channel blocker; $2 \mathrm{mg} / \mathrm{kg})$. Systemic administration of $1(5-40 \mathrm{mg} / \mathrm{kg})$ increased the number of Fos positive cells in the periaqueductal gray. The present study has demonstrated for the first time that $\mathbf{1}$ produces consistent antinociception mediated by opioid receptors and endogenous analgesic mechanisms.

$\mathrm{T}_{\mathrm{h}}^{\mathrm{h}}$ he sensation of pain plays a critical role as an alerting mechanism and as a protection system against tissue damage. Despite the protective role of pain, the sensation of pain is known to be modified by endogenous pain inhibitory systems, predominantly through the descending noradrenalin, serotonin, and endogenous opioids. ${ }^{1}$ The activation of the descending systems markedly reduces the transmission of nociceptive information, and, as a consequence, the severity of pain perception is reduced drastically. Both behavioral and in vivo extracellular recording studies have sought to identify the region that produces such analgesic effects. Several loci are known to produce the antinociceptive effects on pain transmission, including the sensory cortex, thalamus, hypothalamus, midbrain, pons, and rostral ventromedial medulla. ${ }^{2}$ Although there are multiple potential target nuclei for modulating pain transmission, following the original report of Reynolds (1969), the periaqueductal gray (PAG) was rapidly established as being important to descending inhibition of spinal nociceptive processing. ${ }^{3}$ Through descending projections, the PAG controls spinal dorsal horn pain transmission neurons and mediates both opioid and stimulation-produced analgesia. ${ }^{4}$ Advances in knowledge on endogenous analgesic systems have shown attractive pharmacological targets for the development of new analgesic drugs. In fact, drugs widely used clinically for analgesia, such as opioids and antidepressants, act by enhancing the tone of the descending pain inhibition pathways.

Most existing analgesics for persistent pain have a high side effect burden and do not reduce pain in all treated individuals. ${ }^{5}$ Therefore, the development of new agents with more powerful analgesic activities and with lesser side effects is, at present, of

Received: October 22, 2012

Published: February 25, 2013 
great interest. Since ancient times, natural products have been an important source of analgesic agents. ${ }^{6}$ One of the most important analgesic drugs employed in clinical practice today continues to be the alkaloid morphine. Data from 1981 to 2010 indicate that almost forty percent of the drugs approved are based on natural products. ${ }^{7}$ In line with these observations, there is currently a strong interest of pharmaceutical companies in plant-derived secondary metabolites for the development of new drugs, with potentially lesser side effects. ${ }^{7}$

Hecogenin is a steroidal sapogenin obtained from plants of the genus Agave (commonly known as "sisal"), belonging to the family Agavaceae, which are distributed widely in tropical and subtropical regions of the world. ${ }^{8}$ Agave species possess commercial importance both as a source of industrial fibers and medicinally, as they are used in Chinese folk medicine in the treatment of scabies, tumors, pain, and inflammatory disorders. ${ }^{9}$ In addition, hecogenin is an important precursor for the synthesis of steroidal hormones. ${ }^{10}$ Moreover, hecogenin has a wide spectrum of pharmacological activities already reported. ${ }^{11-13}$ As a function of the antiproliferative activity of hecogenin, the most studied effects of this sapogenin are those related to cancer research. ${ }^{11}$ In addition, Cerqueira et al. (2012) showed that hecogenin presents a significant gastroprotective effect that seems to be mediated by $\mathrm{K}^{+}{ }_{\text {ATP }}$ channel opening. ${ }^{12}$ Peana et al. (1997) demonstrated anti-inflammatory activity of hecogenin by reducing paw edema induced by carrageenin. ${ }^{13}$ The antiedematogenic effect of hecogenin was more efficacious than that obtained with indomethacin or dexamethasone at equimolar dose. The present study was undertaken to investigate the antinociceptive properties of hecogenin acetate (1), as well as its effect on the neuronal activity of the periaqueductal gray.

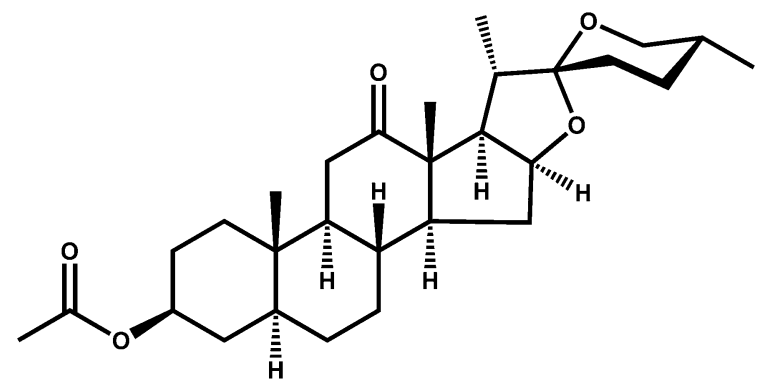

hecogenin acetate (1)

\section{RESULTS AND DISCUSSION}

The present study demonstrated, for the first time, the antinociceptive properties of hecogenin acetate (1). The systemic administration of $\mathbf{1}$, at doses that did not induce any motor performance alteration, inhibited the tail flick reflex, and this effect was prevented by both nonselective and selective antagonists of opioid receptors. In addition, 1 was able to promote neuron activation within the periaqueductal gray, a main site of descending pain-inhibitory pathways. Taken together, these data suggest that 1 induces a long-lasting antinociceptive effect mediated by opioid receptors and activation of endogenous analgesic mechanisms.

The antinociceptive property of $\mathbf{1}$ was evaluated using the tail flick test, which identifies mainly central analgesics. ${ }^{18}$ The intraperitoneal administration of $1(5-40 \mathrm{mg} / \mathrm{kg})$ produced a dose-dependent enhancement of the reaction time in the tail- flick test (Figure $1 ; p<0.05$ ), an effect that lasted $5 \mathrm{~h}$. The administration of morphine $(5 \mathrm{mg} / \mathrm{kg} \mathrm{sc})$, a reference drug

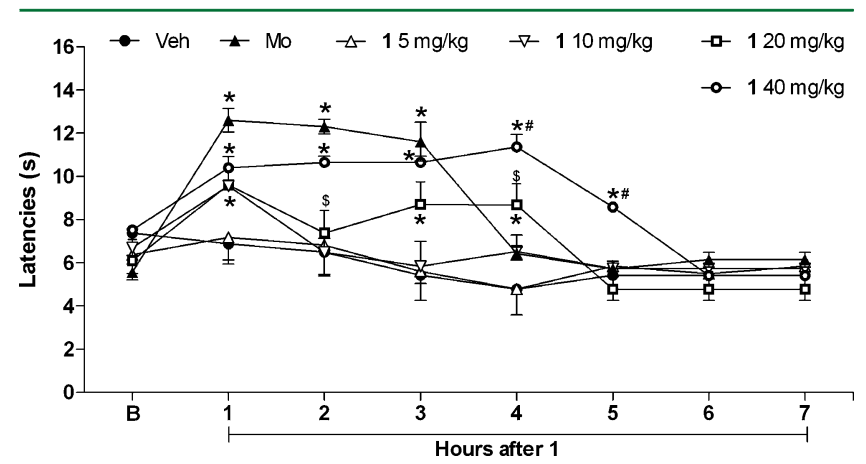

Figure 1. Characterization of the antinociceptive effect of hecogenin acetate (1) in the tail flick test. For the dose-response analysis, the effects of increasing doses of 1 ( 5 to $40 \mathrm{mg} / \mathrm{kg}$; ip) were tested. To evaluate the time-course of the antinociceptive effect, the thermal nociceptive threshold was evaluated before (B) and up to $7 \mathrm{~h}$ following administration of 1 or vehicle (Veh; Tween 20 5\%; control group). Morphine (Mo; $5 \mathrm{mg} / \mathrm{kg} \mathrm{sc}$ ), the reference drug, was administered 40 min before the tail flick test. Data are expressed as means \pm SEM; $n=$ 6 mice per group. *Significantly different from control group $(p<$ $0.05)$; \#significantly different from morphine-treated group $(p<0.05)$; $\$$ significantly different from $140 \mathrm{mg} / \mathrm{kg}$ group $(p<0.05)$. Two-way ANOVA followed by Bonferroni's test was used.

used, caused a significant increase in the latency response for 3 $\mathrm{h}$ after administration $(p<0.05)$. In this test, the antinociceptive effect of 1 showed a similar efficacy and longlasting effect to that of morphine. Moreover, relaxing or motor deficit effects were discarded, since administration of $\mathbf{1}$ at antinociceptive doses $(40 \mathrm{mg} / \mathrm{kg})$ did not affect the motor performance of mice in the Rotarod test (Figure 2). As

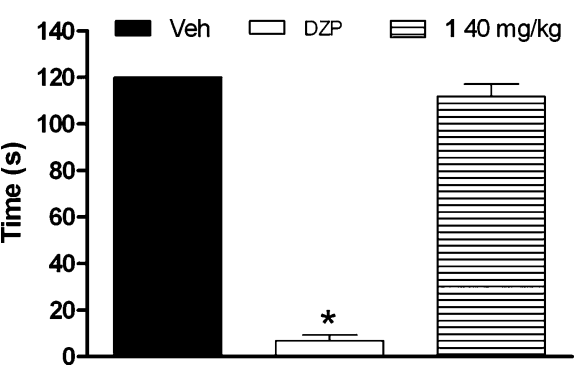

Figure 2. Effects of hecogenin acetate (1) on the Rotarod test. Bar graphs representing the run time on the Rotarod $1 \mathrm{~h}$ after the administration of $1(40 \mathrm{mg} / \mathrm{kg})$ or vehicle (Veh; Tween $20 \mathrm{5 \%}$; control group). Diazepam (DZP; $10 \mathrm{mg} / \mathrm{kg}$ ), the reference drug, was administered $30 \mathrm{~min}$ before testing. Data are reported as means \pm SEM; $n=6$ mice per group. *Significantly different from the control group $(p<0.001)$ as determined by ANOVA followed by Tukey's test.

expected, the central nervous system depressant diazepam (10 $\mathrm{mg} / \mathrm{kg}$, ip) reduced the time of mice on the Rotarod after 30 min of treatment with this standard drug $(p<0.001)$. This result indicates that the effects of $\mathbf{1}$ observed in the nociceptive test do not result from alterations in locomotor activity of the animals, confirming that this sapogenin acetate induces an antinociceptive effect.

Sapogenins, such as hecogenin, are the aglycone nonsugar portions of the saponin molecule used for the semisynthesis of medicinal steroids, such as corticosteroids, sexual hormones, 
and steroid diuretics. As suggested by the chemical structure, 1 exhibits anti-inflammatory properties. ${ }^{13}$ Inflammation causes the induction of cyclooxygenase-2, leading to the release of prostanoids, which contribute to the development of peripheral and central sensitization, increasing excitability, and reducing the pain threshold. ${ }^{19,20}$ Despite the diverse chemical structures of anti-inflammatory drugs, their antinociceptive effect is mainly due to a common property of prostanoid production inhibition. ${ }^{21}$ Accordingly, it is possible that the antinociceptive effect of 1 could also be dependent on its anti-inflammatory properties. ${ }^{13}$ On the other hand, in the present study, the antinociceptive effect of $\mathbf{1}$ was demonstrated in the tail flick test, indicating a central antinociceptive effect for this molecule. The thermal model of the tail flick test is considered to be a spinal reflex, but could also involve higher neural structures. ${ }^{18,22}$ These characteristics of this model are helpful tools to investigate the site of action of antinociceptive agents. In addition, from a pharmacological point of view, there is a consensus that this test is efficient only for revealing the activity of opioid analgesics. ${ }^{18}$ On the basis of this theory, the effects of the pharmacological blockage of opioid receptors on the antinociceptive activity of $\mathbf{1}$ were evaluated. The maximal antinociception produced by $1(40 \mathrm{mg} / \mathrm{kg})$ was completely prevented in mice pretreated with naloxone $(5 \mathrm{mg} / \mathrm{kg}$ ip; 15 min before), a nonselective opioid receptor antagonist, suggesting an opioid-like activity for this sapogenin acetate (Figure 3a). Similarly, the administration of the $\mu$-opioid receptor antagonist CTOP $(1 \mathrm{mg} / \mathrm{kg}$ ip) $30 \mathrm{~min}$ after the administration of $\mathbf{1}$ blocked the observed antinociceptive effect (Figure $3 b)$. Pretreatment with the $\kappa$-opioid receptor antagonist nor-BNI $(0.5 \mathrm{mg} / \mathrm{kg} \mathrm{sc} ; 15 \mathrm{~min}$ before $)$ or the $\delta$-opioid receptor antagonist naltrindole $(3 \mathrm{mg} / \mathrm{kg} \mathrm{sc} ; 5 \mathrm{~min}$ before $)$ also prevented 1-induced antinociception (Figure $3 \mathrm{~b}$ ). In addition, the administration of the opioid receptor antagonists, at a similar range of dose, did not modify per se the reaction time in the tail-flick test (data not shown). These results suggest that opioid receptors play a major role in the antinociceptive effect of 1 .

It was recently demonstrated that $\mathbf{1}$ shows gastroprotective effects dependent on ATP-sensitive $\mathrm{K}^{+}\left(\mathrm{K}^{+}{ }_{\text {ATP }}\right)$ channels, since its effects were reversed by pretreatment with glibenclamide, a potent blocker of these channels. ${ }^{11}$ Several in vivo studies have suggested that $\mathrm{K}^{+}$ATP channels are involved in opioid-induced analgesia. Glibenclamide, dose-dependently decreased the antinociceptive response of morphine, levorphanol, methadone, and buprenorphine. ${ }^{23-25}$ On the other hand, $\mathrm{K}^{+}$ATP channel openers are able to potentiate the antinociceptive response of morphine. ${ }^{26-28}$ In addition, previous findings implicate the release of endogenous opioids in the mediation of antinociceptive effects of $\mathrm{K}^{+}{ }_{\text {ATP }}$ channel openers. ${ }^{26}$ Aiming to investigate this idea, the effects of pharmacological blockage of $\mathrm{K}_{\text {ATP }}^{+}$channels on the antinociceptive activity of $\mathbf{1}$ were evaluated. The antinociceptive effect of 1 (40 mg/kg) was completely prevented in mice pretreated with glibenclamide (2 $\mathrm{mg} / \mathrm{kg}$ ip; $30 \mathrm{~min}$ before) (Figure 4). The function of 1 in $\mathrm{K}_{\text {ATP }}^{+}$channels reinforces the hypothesis of the involvement of the opioid system in their mechanisms of antinociception proposed in the present work.

Anatomical and physiological studies conducted in the 1960s and 1970s identified the periaqueductal gray and its descending projections to the spinal cord dorsal horn as a primary anatomical pathway that mediates descending pain-inhibitory mechanisms. $^{3,29}$ The PAG projects to the ventromedial
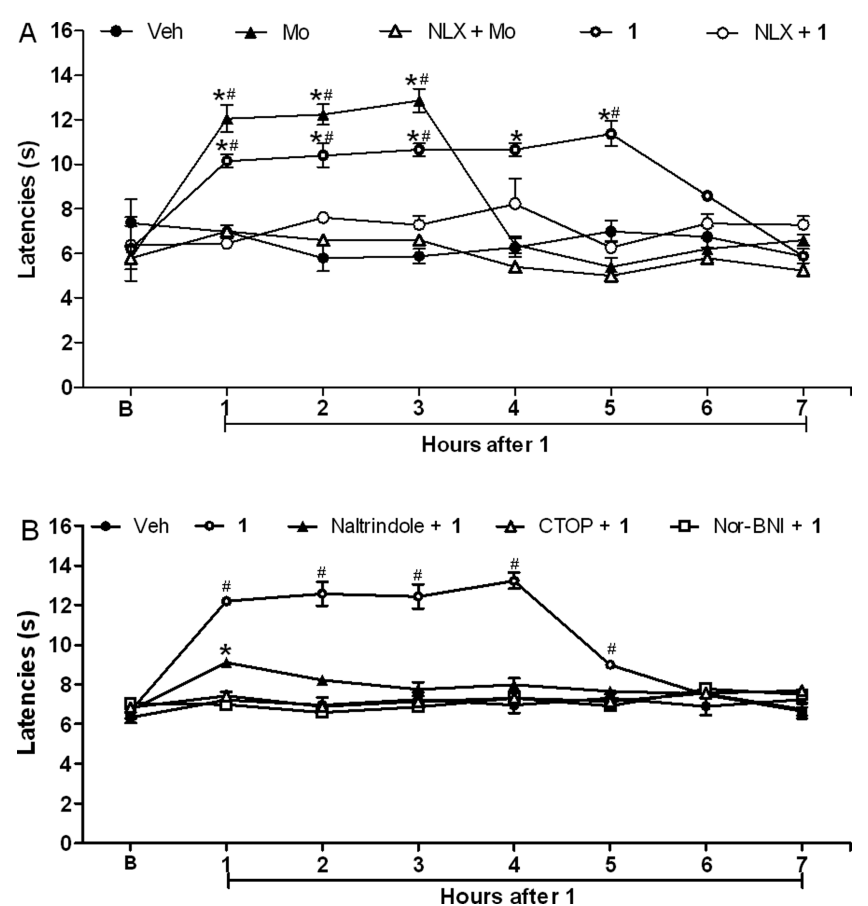

Figure 3. Effects of the pharmacological blockage of opioid receptors on the antinociceptive effect of hecogenin acetate (1). The thermal nociceptive threshold was evaluated before (B) and up to $7 \mathrm{~h}$ following administration of 1 (40 mg/kg) or vehicle (Veh; Tween $205 \%$; control group). (A) Effects of naloxone, a nonselective opioid receptor antagonist, on the antinociceptive effect of 1 . Naloxone (NLX; $5 \mathrm{mg}$ / $\mathrm{kg}$ ip) was administered $15 \mathrm{~min}$ before the administration of $\mathbf{1}$, morphine, or vehicle. Morphine (5 mg/kg sc) was administered 40 min before the tail flick test. (B) Effects of the $\mu$-opioid receptor antagonist CTOP $(1 \mathrm{mg} / \mathrm{kg}$ ip; $30 \mathrm{~min}$ after 1$)$, the $\kappa$-opioid receptor antagonist nor-BNI $(0.5 \mathrm{mg} / \mathrm{kg} \mathrm{sc} ; 15 \mathrm{~min}$ before 1$)$, and the $\delta$-opioid receptor antagonist naltrindole $(3.0 \mathrm{mg} / \mathrm{kg} \mathrm{sc} ; 5 \mathrm{~min}$ before 1$)$ on the antinociceptive effect of 1 . Data are expressed as means \pm SEM; $n=6$ mice per group. Two-way ANOVA followed by Bonferroni's test was used. Panel A: *Significantly different from control group $(p<0.05)$; \#significantly different from naloxone-treated groups $(p<0.05)$. Panel B: *Significantly different from control group $(p<0.05)$; ${ }^{\#}$ significantly different from remaining groups $(p<0.05)$.

medulla, which, in turn, sends its output to dorsal horn laminae important in nociceptive functions. ${ }^{30}$ Since the PAG has a pivotal role in endogenous analgesia mechanisms and is also recognized as the central site of action of analgesic opioids, in the present study the ability of $\mathbf{1}$ to promote activation of neurons within the PAG was evaluated. ${ }^{29,30}$ For this purpose, immunohistochemical detection of the protein product (Fos) of the c-fos proto-oncogene was carried out. Vehicle-treated mice showed low levels of Fos expression in the periaqueductal gray (Figure 5A and F). However, following systemic administration of $1(5-40 \mathrm{mg} / \mathrm{kg})$, there was a major increase in the number of Fos-positive cells in the PAG when compared to the control group ( $p<0.001$; Figure 5B, C, D, and E). Therefore, by using Fos expression as a neural marker, it was possible to suggest that $\mathbf{1}$ induces PAG activation. The immediate early gene $c$-fos is rapidly and transiently expressed in neurons in response to stimulation. ${ }^{31}$ The gene encodes for the nuclear protein Fos, and the levels of the protein peak about $2 \mathrm{~h}$ after induction of gene transcription. ${ }^{32}$ In line with literature data, the effect of 1 on Fos expression was observed 2 $\mathrm{h}$ after the drug injection. The involvement of PAG in the 


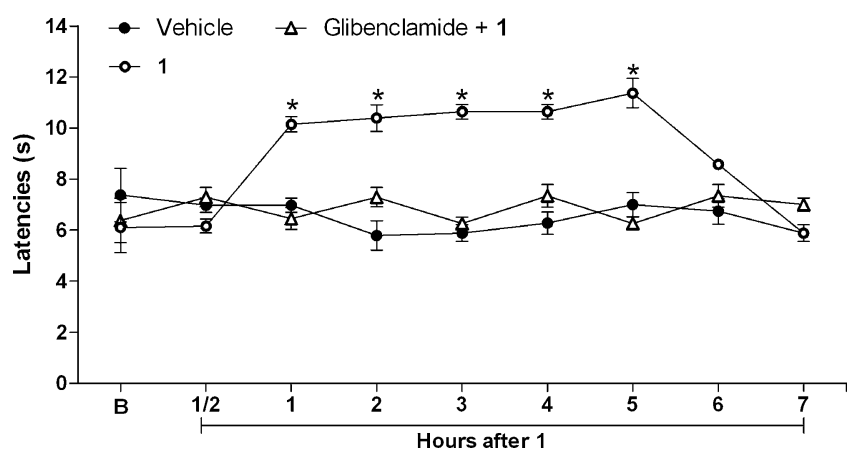

Figure 4. Effects of the pharmacological blockage of ATP-sensitive $\mathrm{K}^{+}$ $\left(\mathrm{K}_{\mathrm{ATP}}^{+}\right)$channel on the antinociceptive effect of hecogenin acetate $(\mathbf{1})$. The thermal nociceptive threshold was evaluated before (B) and up to $7 \mathrm{~h}$ following administration of $\mathbf{1}(40 \mathrm{mg} / \mathrm{kg}$ ) or vehicle (Veh; Tween 20 5\%; control group). Figure shows the effects of glibenclamide, a $\mathrm{K}_{\text {ATP }}^{+}$channel blocker, on the antinociceptive effect of 1 . Glibenclamide $(2 \mathrm{mg} / \mathrm{kg}$ ip) was administered $30 \mathrm{~min}$ before the administration of 1 . Data are expressed as means \pm SEM; $n=6$ mice per group. Two-way ANOVA followed by Bonferroni's test was used. *Significantly different from remaining groups $(p<0.05)$.
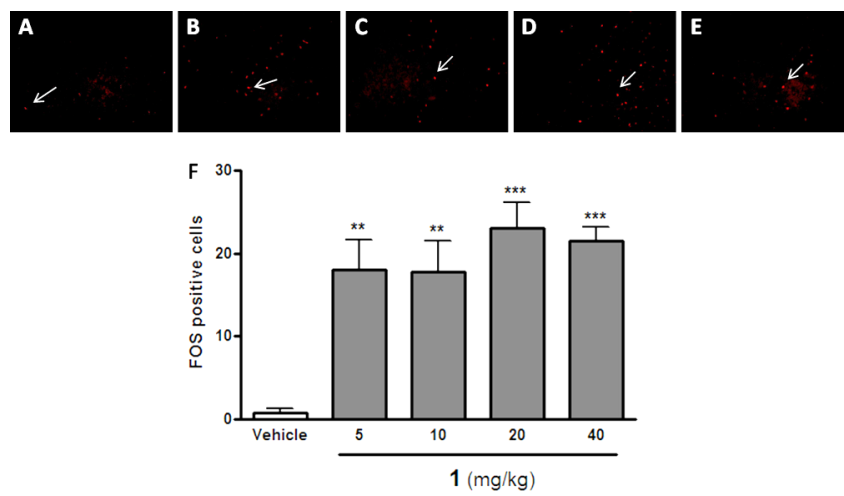

Figure 5. Imunofluorescence for Fos protein. The white arrows point to Fos-positive neurons in the periaqueductal gray. Vehicle (A) or hecogenin acetate (1) (B: 5, C: 10, D: 20, E: $40 \mathrm{mg} / \mathrm{kg}$ ) was administered by the intraperitoneal route $2 \mathrm{~h}$ before perfusion. The bar graph shows (below and right side) average FOS-positive cells compared with the vehicle-treated group (white bar). Data are reported as means \pm SEM; $n=6$ mice per group, $* * p<0.01$ and $* * * p$ $<0.001$ vs control group as determined by ANOVA followed by Tukey's test.

antinociceptive effect of hecogenin was not presently evaluated, but data from the literature have established the measure of $c$ fos expression as a valid tool for the study of the neural correlates of nociception. ${ }^{33}$ Visualization of $c$-fos expression allows a precise anatomical record of neuronal populations that are activated during nociceptive processing and has advanced the understanding of where many analgesic drugs and endogenous analgesic systems act to reduce pain. ${ }^{34}$

In conclusion, the present study has demonstrated for the first time that systemic administration of $\mathbf{1}$, at doses that did not induce motor performance alterations, produced a consistent antinociceptive effect, possibly mediated by the opioid system and descending pain-inhibitory pathways activation. However, a more in-depth evaluation of the mechanisms involved in 1induced antinociception is still necessary.

\section{EXPERIMENTAL SECTION}

General Experimental Procedures. Experiments were performed on male Swiss Webster mice $(20-25 \mathrm{~g})$ obtained from the Animal Facilities of Centro de Pesquisas Gonçalo Moniz. Animals were housed in temperature-controlled rooms $\left(22-25{ }^{\circ} \mathrm{C}\right)$, under a 12:12 h light-dark cycle, with access to water and food ad libitum until use. All behavioral tests were performed between 8:00 A.M. and 5:00 P.M., and animals were used only once. Animal care and handling procedures were in accordance with the International Association for the Study of Pain guidelines for the use of animals in pain research and the Institutional Animal Care and Use Committee FIOCRUZ CPqGM 009/2011. ${ }^{14}$ Every effort was made to minimize the number of animals used and to avoid any discomfort.

Test Compounds and Administration. The test compounds used in this study were hecogenin acetate (1), glibenclamide (ATPsensitive $\mathrm{K}^{+}$channel blocker), naloxone (nonselective antagonist of opioid receptors), naltrindole ( $\delta$-opioid receptor antagonist), and norbinaltorphimine (Nor-BNI; $\kappa$-opioid receptor antagonist), which were obtained from Sigma Chemical Company (St. Louis, MO, USA). DPhe-Cys-Tyr-D-Trp-Orn-Thr-Pen-Thr amide (CTOP; $\mu$-opioid receptor antagonist) was purchased from Tocris Bioscience (Bristol, UK), and diazepam and morphine were from Cristália (Itapira, São Paulo, Brazil). Hecogenin acetate (95\% purity) was dissolved in Tween $205 \%$ plus physiological saline, and the remaining compounds were dissolved in physiological saline. The test compounds were administered by intraperitoneal (ip) or subcutaneous (sc) routes at doses and conditions previously standardized. ${ }^{15}$

Tail Flick Test. The warm-water tail withdrawal test in mice was conducted as described previously, with minor modifications. ${ }^{16}$ Before the day of the experiment, each animal was habituated to the restraint cylinder for five consecutive days ( $20 \mathrm{~min}$ per day). On the day of the experiment, mice were placed in a restraining cylinder, and the tail tip $(2 \mathrm{~cm})$ was immersed in a water bath at $50 \pm 0.5{ }^{\circ} \mathrm{C}$. The latency for the tail withdrawal reflex was measured. Each trial was terminated after $16 \mathrm{~s}$ to minimize the probability of skin damage. The tail flick latency was measured before (baseline) and after treatment.

Assay of Motor Function. To evaluate possible nonspecific muscle-relaxant or sedative effects of hecogenin acetate (1), mice were submitted to the Rotarod test. ${ }^{17}$ The Rotarod apparatus (Insight, Ribeirão Preto, Brazil) consisted of a bar with a diameter of $3 \mathrm{~cm}$, subdivided into five compartments. The bar rotated at a constant speed of $6 \mathrm{rpm}$. The animals were selected $24 \mathrm{~h}$ previously by eliminating those mice that did not remain on the bar for two consecutive periods of $120 \mathrm{~s}$. Animals were treated with diazepam (10 $\mathrm{mg} / \mathrm{kg}$, ip), 1 (40 mg/kg, ip), or vehicle $(200 \mu \mathrm{L}$, ip) and $40 \mathrm{~min}$ afterward were placed on the rotating rod. The resistance to falling was measured up to $120 \mathrm{~s}$. The results are expressed as the average time (s) the animals remained on the Rotarod in each group.

Immunohistochemical Studies. Two hours after the intraperitoneal injection of $\mathbf{1}(5,10,20$, or $40 \mathrm{mg} / \mathrm{kg})$ or vehicle, mice $(n=$ 6 , per group) were perfused, and the brains were collected for immunofluorescence processing for Fos protein. Frozen serial transverse sections of $20 \mu \mathrm{m}$ containing the periaqueductal gray were collected on gelatinized glass slides. The tissue sections were stored at $-70{ }^{\circ} \mathrm{C}$ until use. The sections were washed with phosphate buffer $(0.01 \mathrm{M})$ saline isotonic (PBS) three times for $5 \mathrm{~min}$ and incubated with $0.1 \mathrm{M}$ glycine in PBS for $10 \mathrm{~min}$. Nonspecific protein binding was blocked by incubation of the sections for $30 \mathrm{~min}$ in a solution containing $1 \%$ bovine serum albumin. After this, sections were incubated overnight with rabbit anti-Fos (Santa Cruz Biotechnology, Santa Cruz, CA, USA) as primary antibodies. Afterward, the sections were incubated for $1 \mathrm{~h}$ with donkey anti-rabbit Alexa Fluor 594 as secondary antibodies (Molecular Probes, Eugene, OR, USA). The coverslip was mounted with Fluoromount G (Electron Microscopy Sciences, Hatfield, PA, USA). As an immunohistochemistry control for nonspecific labeling, sections were incubated without primary antibody. After each stage, slides were washed with PBS three times for $5 \mathrm{~min}$ 
Acquisition and Analyses of Images. Pictures from the periaqueductal gray were acquired for each animal $(n=6$, per group) with an Axioskop 2 Plus (Carl Zeiss, Germany). Neurons were counted by the free software Image J (National Institute of Health) using a plugin (written by the authors) that uses the same level of label intensity to select and count the Fos-positive cells.

Statistical Analysis. All data are presented as means \pm standard error of the mean (SEM) of measurements made on six animals in each group. All data were analyzed using the Prism 5 computer software (GraphPad, San Diego, CA, USA). Comparisons across three or more treatments were made using one-way ANOVA with Tukey's post hoc test or repeated measure two-way ANOVA with Bonferroni's post hoc test used when appropriate. Statistical differences were considered to be significant at $p<0.05$.

\section{AUTHOR INFORMATION}

\section{Corresponding Author}

*Tel: +55-71-31762260. Fax: +55-71-31762272. E-mail: cfv@ ufba.br.

\section{Notes}

The authors declare no competing financial interest.

\section{ACKNOWLEDGMENTS}

This work was supported by grants from Fundação de Amparo à Pesquisa do Estado da Bahia (FAPESB) and Conselho Nacional de Pesquisa (CNPq).

\section{REFERENCES}

(1) Yoshimura, M.; Furue, H. J. Pharmacol. Sci. 2006, 101, 107-117.

(2) Millan, M. J. Prog. Neurobiol. 2002, 66, 355-474.

(3) Reynolds, D. V. Science 1969, 164, 444-445.

(4) Yaksh, T. L.; Rudy, T. A. Pain 1978, 4, 299-359.

(5) Woolf, C. J. Nat. Med. 2010, 16, 1241-1247.

(6) Calixto, J. B.; Beirith, A.; Ferreira, J.; Santos, A. R. S.; CechinelFilho, V.; Yunes, R. A. Phytother. Res. 2000, 14, 401-418.

(7) Newman, D. J.; Cragg, G. M. J. Nat. Prod. 2012, 75, 311-335.

(8) Griffiths, M. Dictionary of Gardening; The Stockton Press: New York, 1997.

(9) Hocking, G. M. A Dictionary of Natural Products; Plexus Publishing, Inc: Medford, NJ, 1997; Vol. 7.

(10) Ghoghari, A. M.; Rajani, M. Chromatographia 2006, 64, 113116.

(11) Corbiere, C.; Liagre, B.; Bianchi, A.; Bordji, K.; Dauca, M.; Netter, P.; Beneytout, J. L. Int. J. Oncol. 2003, 22, 899-905.

(12) Cerqueira, G. S.; Silva, G. S.; Vasconcelos, E. R.; Freitas, A. P. F.; Moura, B. A.; Macedo, D. S.; Souto, A. L.; Barbosa Filho, J. M.; Leal, L. K. A.; Brito, G. A. C.; Souccar, C.; Viana, G. S. B. Eur. J. Pharmacol. 2012, 683, 260-269.

(13) Peana, A. T.; Moretti, M. D.; Manconi, V.; Desole, G.; Pippia, P. Planta Med. 1997, 63, 199-202.

(14) Zimmermann, M. Pain 1983, 16, 109-110.

(15) Santos, G. G. L.; Casais e Silva, L. L.; Soares, M. B. P.; Villarreal,

C. F. Toxicon 2012, 60, 1005-1012.

(16) Lamberts, J. T.; Jutkiewicz, E. M.; Mortensen, R. M.; Traynor, J.

R. Neuropsychopharmacology 2011, 36, 2041-2053.

(17) Kuribara, H.; Higuchi, Y.; Takadoro, S. Jpn. J. Pharmacol. 1977, 27, 117-126.

(18) Le Bars, D.; Gozariu, M.; Cadden, S. Pharmacol. Rev. 2001, 53, 628-651.

(19) Vane, J. R.; Bakhle, Y. S.; Botting, R. M. Annu. Rev. Pharmacol. Toxicol. 1998, 38, 97-120.

(20) Woolf, C. J. Nature 1983, 306, 686-688.

(21) Burian, M.; Geisslinger, G. Pharmacol. Ther. 2005, 107, 139154.

(22) Jensen, T. S.; Yaksh, T. L. Brain Res. 1986, 363, 99-113.
(23) Narita, M.; Suzuki, T.; Misawa, M.; Nagase, H.; Nabeshima, A.; Ashizawa, T.; Ozawa, H.; Saito, T.; Takahata, N. Brain Res. 1992, 596, 209-214.

(24) Ocaña, M.; Del Pozo, E.; Barrios, M.; Robles, L. I.; Baeyens, J. M. Eur. J. Pharmacol. 1990, 186, 377-378.

(25) Raffa, R. B.; Martinez, R. P. Brain Res. 1995, 677, 277-282.

(26) Lohmann, A. B.; Welch, S. P. Eur. J. Pharmacol. 1999, 385, 119127.

(27) Narita, M.; Takamori, K.; Kawashima, N.; Funada, M.; Kamei, J.; Suzuki, T.; Misawa, M.; Nagase, H. Psychopharmacology 1993, 113, $11-14$.

(28) Vergoni, A. V.; Scarano, A.; Bertolini, A. Life Sci. 1992, 50, 135138.

(29) Yaksh, T. L.; Yeung, J. C.; Rudy, T. A. Brain Res. 1976, 114, 83103.

(30) Heinricher, M. M.; Tavares, I.; Leith, J. L.; Lumb, B. M. Brain Res. Rev. 2009, 60, 214-225.

(31) Morgan, J. I.; Curran, T. Annu. Rev. Neurosci. 1991, 14, 421451.

(32) Miiller, R.; Bravo, R.; Burckhardt, J.; Curran, T. Nature 1984, 312, 716-720.

(33) Harris, J. A. Brain Res. Bull. 1998, 45, 1-8.

(34) Lantéri-Minet, M.; Weil-Fugazza, J.; de Pommery, J.; Menétrey, D. Neuroscience 1994, 58, 287-298. 